\title{
Quercetin Ameliorate Oxidative/Nitrosative Stress in The Brain of Rats Exposed to Intermittent Hypobaric Hypoxia
}

\author{
Chiş, I. C. ;* Baltaru, D.; Dumitrovici, A.; Coseriu, A. ; Radu, B. C.; \\ Moldovan, R.; Mureşan, A.
}

Rev. Virtual Quim., 2016, 8 (2), 369-383. Data de publicação na Web: 14 de março de 2016

http://rvq.sbq.org.br

\section{Quercetina na Melhora do Estresse Oxidativo/Nitrosativo no Cérebro de Ratos Expostos a Hipóxia Hipobárica Intermitente}

\begin{abstract}
Resumo: Exposição à alta altitude é um extremo fisiológico do estresse oxidativo/nitrosativo, onde o cérebro é o tecido mais sensível do corpo. A quercetina (Que) é um flavonóide natural abundante em frutas e legumes. O presente estudo investigou mudanças específicas na região do cérebro do estriado, hipocampo e córtex, sobre marcadores de estresse oxidativo/nitrosativo, e os efeitos da administração de Que em ratos expostos à hipóxia hipobárica intermitente (IHH). Ratos Wistar machos foram expostos a curto prazo (dois dias) ou de longo prazo (4 semanas, 5 dias/semana) à IHH em uma câmara hipobárica. Metade dos ratos receberam Que $(30 \mathrm{mg} / \mathrm{kg}$ de peso corporal) diariamente, antes de cada exposição à $\mathrm{IHH}$. Os ratos de controle foram mantidos sob condições de normóxia normobárica ( $\mathrm{Nx}$ ), tratando de uma maneira correspondente. Após a última exposição à $\mathrm{IHH}$, o cérebro foi removido e os marcadores de estresse oxidativo/nitrosativo foram determinados nas três partes de tecido homogeneizado do cérebro (estriado, hipocampo e córtex): os radicais livres (malondialdeído, MDA e proteínas carboniladas, CP), nitrito mais nitrato (NOx) produção e atividade de enzimas antioxidantes (superóxido dismutase, SOD, e catalase, CAT). Os resultados indicam um aumento na produção de radicais livres e de NOx, com uma redução do sistema de defesa antioxidante em todas as três regiões do cérebro, após a exposição à $\mathrm{IHH}$. $\mathrm{O}$ tratamento com Que reduziu significativamente os radicais livres e produção de NOx e significativamente aumentou os níveis de SOD e CAT em todos as três regiões do cérebro após a exposição à IHH. A observação sugere que a hipóxia afeta diferencialmente as regiões do cérebro, e Que fornece neuroproteção substancial contra danos oxidativo/nitrosativo induzido por $\mathrm{IHH}$.
\end{abstract}

Palavras-chave: Neuroproteção; hipóxia hipobárica intermitente; quercetina; estresse oxidativo/nitrosativo.

\begin{abstract}
High altitude exposure is an extreme physiological oxidative/nitrosative stress and the brain is more sensitive tissue of the body. Quercetin (Que) is a natural flavonoid abundant in fruits and vegetables. The present study investigated the brain region specific changes in striatum, hippocampus and cortex on oxidative/nitrosative stress markers and the effects of Que administration in rats exposed to intermittent hypobaric hypoxia $(\mathrm{IHH})$. Wistar male rats were exposed to short-term $(2$ days) or long-term (4 weeks, 5 days/week) IHH in a hypobaric chamber. Half of the rats received Que $(30 \mathrm{mg} / \mathrm{kg}$ body weight) daily, before each $\mathrm{IHH}$ exposure. Control rats were kept under normobaric normoxia ( $\mathrm{Nx}$ ) and treated in a corresponding manner. After the last exposure to $\mathrm{IHH}$, the brain was removed and the oxidative/nitrosative stress markers were determined in the three parts of the brain (striatum, hippocampus and cortex) tissue homogenate: the free radicals (malondialdehyde, MDA and carbonylated proteins, CP), nitrite plus nitrate (NOx) production and activity of antioxidant enzymes (superoxide dismutase, SOD and catalase, CAT). Results indicate an increase in free radicals and NOx production and a decrease of the antioxidant defense system in all the three regions of the brain after IHH exposure. The Que treatment significantly lower the free radicals and NOx production and significantly higher the SOD and CAT levels in all the three brain regions after IHH exposure. The observation suggests that the hypoxia differentially affects the brain regions and Que provides substantial neuroprotection against IHH-induced oxidative/nitrosative damage.
\end{abstract}

Keywords: Neuroprotection; intermittent hypobaric hypoxia; Quercetin; oxidative/nitrosative stress.

\footnotetext{
* University of Medicine and Pharmacy, Department of Physiology, 1-3, Clinicilor Street, "luliu Hatieganu", RO 400023, ClujNapoca, Romania. Phone: +40-744-707080; Fax +40-264-597257.

$M$ ichis@umfcluj.ro DOI: $10.5935 / 1984-6835.20160027$
}

Rev. Virtual Quim. |Vol 8| | No. 2| |369-383| 


\section{Quercetin Ameliorate Oxidative/Nitrosative Stress in The Brain of Rats Exposed to Intermittent Hypobaric Hypoxia Irina Camelia Chiş, ${ }^{\mathrm{a}, *}$ Doina Baltaru, ${ }^{\mathrm{b}}$ Anca Dumitrovici, ${ }^{\mathrm{c}}$ Andrei
Coseriu, ${ }^{\mathrm{d}}$ Bogdan Cristian Radu, ${ }^{\mathrm{d}}$ Remus Moldovan, ${ }^{\mathrm{a}}$ Adriana Mureşan ${ }^{\mathrm{a}}$}

a University of Medicine and Pharmacy, Department of Physiology, 1-3, Clinicilor Street, "Iuliu Hatieganu", RO 400023, Cluj-Napoca, Romania. Phone: +40-744-707080; Fax +40-264-597257.

b “Constantin Papilian” Military Emergency Hospital, Cluj-Napoca, Romania.

c "I. Chiricuta"Oncologic Institute, Cluj-Napoca, Romania.

'University of Medicine and Pharmacy "Iuliu Haţieganu”, Cluj-Napoca, Romania.

*ichis@umfcluj.ro

Recebido em 14 de março de 2016. Aceito para publicação em 14 de março de 2016

\section{Introduction}

2. Materials and methods

2.1. Drugs and chemicals

2.2. Animals

2.3. Intermittent hypobaric hypoxia-adapted rat model

2.4. Experimental design

2.5. Preparation of biological samples

2.6. Measurement of biochemical markers of oxidative/nitrosative stress in different brain regions (e.g. striatum, hippocampus and cortex)

3. Results

4. Discussion

5. Conclusion

\section{Introduction}

Exposure to hypobaric hypoxia $(\mathrm{HH})$ in experimental conditions is similarly to high altitude (HA) environmental conditions. Peoples travel to HA for various reasons including tourism and research are exposed to $\mathrm{HH}$ which is responsible for severely affects the central nervous system (CNS) including HA cerebral edema, motor impairment, mental dysfunction, learning disability and memory impairment. ${ }^{1}$ Hypoxic hypoxia met en HA is known as altitude hypoxia or HH. Many recent researches suggested that exposure to HA decrease the partial pressure of oxygen and increases production of reactive oxygen and nitrogen species (RONS) by: altered mitochondria 
electron transport chains, activating enzymes: nicotinamide adenine dinucleotide phosphate (NADPH) oxidase, xanthine oxidase/reductase, nitric oxide synthases (NOS), etc., as well as by the depletion of cellular enzymatic and non-enzymatic antioxidants. $^{2-5}$ The brain is more sensitive to oxidative/nitrosative stress due to: high rate of $\mathrm{O}_{2}$ utilization due to higher metabolic rate, an abundant presence of polyunsaturated fatty acid, a deficiency of the antioxidant defense and high content of transition metals like copper and iron in several regions which could lead to formation of hydroxyl radical by Fenton reaction. ${ }^{6}$ Exposure to $\mathrm{HH}$ induces neurodegeneration, ${ }^{7}$ synaptic plasticity ${ }^{8}$ and apoptosis $^{9}$ in the brain and the oxidative/nitrosative stress is proposed that may be involved in neurodegeneration and memory loss at HA. ${ }^{4}$

Exposure to intermittent hypobaric hypoxia (IHH) is similar with ischemia/reperfusion injury, the growth RONS production during the phase of reoxygenation of $\mathrm{IHH}$. The severity of lesions produced by exposure to $\mathrm{IHH}$ is distinct in different regions of the brain, the severity depending on the degree and duration of exposure. Recent reports on the differential susceptibility of brain regions to hypoxia suggest that the hippocampus is more vulnerable to $\mathrm{HH}$ stress compared with the cortex and striatum because there are more glutaminergic neurons. $^{10,11}$

In conditions of $\mathrm{HH}$ the nuclear factor kappa B (NF-kB) is activated which increases the expression of hypoxia inducible factor-1 alpha (HIF-1 $\alpha) .{ }^{5,12}$ The HIF-1 $\alpha$ activates over 100 genes involved inclusively in erythropoiesis, angiogenesis, energy metabolism, proliferation/cell survival, apoptosis, etc. and to generation of nitric oxide (NO). ${ }^{2,5,13}$ Alteration of NO production plays an important role in brain injury in conditions of hypoxia/reoxigenation. ${ }^{14}$ NO produced in excess in the brain under the action of hypoxia-induced neuronal nitric oxide synthases (nNOS), rapidly reacts with superoxide anion to form peroxynitrite (ONOO'), a more toxic metabolite that causes brain injury. ${ }^{15}$ The peroxynitrite is responsible for proteins denaturation, lipid peroxidantion, DNA damage and depletes antioxidant defenses. ${ }^{16}$ nNOS is mainly expressed in brain tissue and excess nNOS expression indicates increased production of NO and lipid peroxidation. ${ }^{16-18}$ Hypoxia stimulates glutaminergic neurons determining the opening of calcium channels through NMDA receptors, thus increasing intracellular calcium levels. High calcium levels activate nNOS and NO and lipid peroxidation. ${ }^{16-18}$ Hypoxia stimulates glutaminergic neurons determining the opening of calcium channels through NMDA receptors, thus increasing intracellular calcium levels. High calcium levels activate nNOS and increase synthesis of NO, because the nNOS is a $\mathrm{Ca}^{2+} /$ calmodulin dependent isoenzyme. $^{19,20}$

Quercetin is an important member of the flavonoids family, polyphenolic natural antioxidants, present in large numbers in fruits, vegetables, spices, seeds, red wine, tea, chocolate, etc. ${ }^{20-22}$ This flavonoid has anti-inflammatory, anti-blood coagulation, anti-tumoral, anti-thrombotic, anti-apoptotic and antioxidant activities ${ }^{23}$ and it is used due to your beneficial health effects in various diseases such as osteoporosis, diabetes, certain forms of cancer, pulmonary and cardiovascular diseases but also against aging. ${ }^{24-26}$ Recent reports has shown that Quercetin has the neuroprotective and cognitive enhancing effects, ameliorates memory impairment and neurodegeneration, neuroprotective effects due to its strong antioxidant activity. ${ }^{27-30}$ It has also been reported that there are cognitive enhancing effects of Quercetin in Parkinson's disease, streptozotocin-induced diabetes and colchicine- and scopolamine-induced memory impairment. ${ }^{27,31,32}$ Previous studies showed that Quercetin improves neurogenesis and synaptogenesis in hippocampus. $^{33}$ Studies on the differential susceptibility of brain regions to hypoxia suggest that Quercetin and can reverse $\mathrm{HH}$ induced memory impairment by decreasing oxidative stress-mediated neurodegeneration in hippocampal regions of the brain. ${ }^{23,34}$ 
These findings suggest that Quercetin can be used as a potential therapeutic agent to improve $\mathrm{HH}$-induced memory dysfunction and other neurodegenerative disorders.

The present study aims to investigate the involvement of the oxidative/nitrosative stress in $\mathrm{IHH}$-exposure. We studied the timedependent and region-dependent changes of free radicals levels, AO activities and NO production in striatum, hippocampus and cortex after exposure to IHH for 2 days and 4 weeks. The study further attempts to demonstrate the potential neuroprotective role of Quercetin in $\mathrm{IHH}$ neuronal injury. We focused on the correlation between Quercetin administration in neurons and the neuroprotective role of Quercetin conducted by decreasing oxidative/nitrosative stress induced in brain by $\mathrm{IHH}$ exposure.

\section{Materials and methods}

\subsection{Drugs and chemicals}

Quercetin (Que) were extracted, dosed and encapsulated at the "PROPLANTA" Applied Vegetal Biotechnologies Center in Cluj-Napoca, Romania. Quercetin was standardized by its chemical composition using high-performance liquid chromatography method to ensure batch-tobatch consistency. The Que was suspended in $0.5 \%$ carboxymethylcellulose (CMC) solution as a vehicle.

\subsection{Animals}

Sixty healthy Wistar albino male rats (three-months-old) were used in this study. The rats were purchased from Experimental Animal House of the Faculty of Medicine of "Iuliu Hatieganu" University of Medicine and Pharmacy of Cluj-Napoca, Romania. The rats' mean weight was 280-300 grams (g) at the start of the trials. All animals used in the experiment were kept for ten days to acclimatize to the Animal House Laboratory Physiology Department's conditions before being introduced in the study. Throughout the entire period of the experiment, all the rats were maintained in special cages artificially illuminated $(12 \mathrm{~h}$ dark $/ 12 \mathrm{~h}$ light cycle), at a temperature of $21-23{ }^{\circ} \mathrm{C}$ and at $50-60 \%$ humidity in the animal room. Animals were fed with distilled water supplied ad libitum and rodent maintenance chow adapted to their weight $(100 \mathrm{mg} / \mathrm{g}$ of weight). All the experiments were performed according to the approved animal-care protocols of the Ethical Committee on Animal Welfare of the "Iuliu Hatieganu" University in accordance with the Romanian Ministry of Health and complying with Guiding Principles in the Use of Animals in Toxicology.

\subsection{Intermittent hypobaric hypoxia- adapted rat model}

The intermittent hypobaric hypoxia (IHH) treatment consisted of intermittently exposing Wistar rats to hypobaric hypoxia (equivalent to an altitude of $5500 \mathrm{~m}$, barometric pressure $380 \mathrm{mmHg}, 12 \% \mathrm{O}_{2}$ and $88 \% \mathrm{~N}_{2}$ ) in hypobaric chamber (in the Physiology Department Animal House Laboratory of the Faculty of Medicine of "Iuliu Hatieganu" University of Medicine and Pharmacy of Cluj-Napoca, Romania) for 2 days (short-term $\mathrm{IHH}$, for 8 hours per day) and for 4 consecutive weeks (long-term IHH, for 8 hours per day, 5 days per week). The rats were taken out of the hypobaric chamber once after every 8 hours exposure in order to receive water and a standard laboratory diet.

The control rats maintained in normobaric normoxia (Nx) conditions (barometric pressure $760 \mathrm{mmHg}, 21 \% \mathrm{O}_{2}$ and $79 \% \mathrm{~N}_{2}$ ) for a corresponding period were kept in the same environment as $\mathrm{IHH}$ rats with free access to water and food except hypoxic exposure. 


\subsection{Experimental design}

The animals were randomly divided into six experimental groups $(n=10): 1^{\text {st }}$ Group (control group, STN $+\mathrm{CMC}$ )- rats maintained in normobaric normoxia $(\mathrm{Nx})$ conditions for short-therm and treated with $\mathrm{CMC} ; 2^{\text {nd }}$ Group (control group, STIHH+CMC)- rats maintained in short-term intermittent hypobaric hypoxia (STIHH) conditions and treated with CMC; $3^{\text {rd }}$ Group (STIHH+Que)rats maintained in STIHH conditions and treated with Que; $4^{\text {th }}$ Group (control group, LTN + CMC)- rats maintained in normobaric normoxia $(\mathrm{Nx})$ conditions for long-therm and treated with CMC; $5^{\text {th }}$ Group (LTIHH+CMC)rats maintained in long-therm intermittent hypobaric hypoxia (LTIHH) conditions and treated with CMC; $6^{\text {th }}$ Group (LTIHH+Que)rats maintained in LTIHH conditions and treated with Que. The Que was suspended in carboxymethylcellulose (CMC, $0.01 \mathrm{~g} / \mathrm{ml}$ ) and orally administered via an intragastric tube, at a dose of $30 \mathrm{mg} / \mathrm{kg}$ once a day for 2 days or for 4 consecutive weeks respectively, 30 minutes before each $\mathrm{IHH}$ exposure. The control groups were treated with vehicle (0.6 $\mathrm{ml}$ of $\mathrm{CMC}$ ) via an intragastric tube. The body weight of the rats was measured at the beginning and end of the experiment.

After 24 hours of the last exposure to normoxia or hypoxia, all the rats were anaesthetized by intraperitoneally administration of sodium pentobarbital (60 $\mathrm{mg} / \mathrm{rat}$ ) and sacrificed by cervical dislocation and the brain of each animal was quickly dissected. Next, the brain was removed immediately, washed with physiologic serum (PS) to remove residual tissues and blood, weighed and the different parts e.g. striatum, hippocampus and cortex were dissected out under ice-cold conditions, placed into tubes, frozen and stored $-80^{\circ} \mathrm{C}$

\subsection{Preparation of biological samples}

The frozen brain tissues were placed into plastic tube and ten percent $(1: 10 \mathrm{w} / \mathrm{v})$ homogenates were prepared with buffer containing $70 \mathrm{mM}$ sucrose, $10 \mathrm{mM}$ Tris- $\mathrm{HCl}$, $0.5 \mathrm{mM}$ EDTA and $210 \mathrm{mM}$ mannitol, supplemented with $0.2 \%$ bovine serum albumine $(\mathrm{pH} 7.4)$ on ice using a Polytron homogenizer (Brinkman Kinematica Switezerland). The homogenate were centrifuged immediately for $30 \mathrm{~min}$ at $10,000 \mathrm{~g}$ at 4 으, and the cellular debris was discarded. The supernatant was allocated into separate tubes, stored at $-80^{\circ} \mathrm{C}$ and used for biochemical assays.

2.6. Measurement of biochemical markers of oxidative/nitrosative stress in different brain regions (e.g. striatum, hippocampus and cortex)

Because free radicals are highly reactive and have a very short lifetime, we indirectly measured their levels in the supernatant from different brain regions (e.g. striatum, hippocampus and cortex) by determining some products of lipid peroxidation and protein oxidation (protein carbonylation).

The lipid peroxidation was measured in the supernatant from different brain regions by quantitfying the amount malodialdehyde (MDA) formed by 2-thiobarbituric acid (TBA) reaction as thiobarbituric acid reactive substances (TBARS) using the method of Conti et al..$^{35}$ This method was used to obtain a spectrofluorimetric measurement of the color produced during the reaction TBA with MDA at $535 \mathrm{~nm}$. MDA levels are expressed as nanomole per milligram protein ( $\mathrm{nmol}$ $\mathrm{MDA} / \mathrm{mg}$ protein).

Protein carbonylation was estimated in the supernatant from different brain regions by measuring protein carbonyls (PC) group levels. The protein carbonyl derivates that are produced through the protein oxidative damage, were determined using the fluorimetric method with 2,4-dinitrophenylhydrazine $(\mathrm{DNPH})^{36}$ The readings were performed using a spectrophotometer at $355-390 \mathrm{~nm}$ and to calculate the remaining carbonyl fragments, the molar extinction 
coefficient with a value of $22,000 / \mathrm{M} / \mathrm{cm}$ was used. The carbonyl-derivative groups' levels are expressed as nanomole per milligram of protein ( $\mathrm{nmol} / \mathrm{mg}$ protein).

The activities of some antioxidant enzymes, superoxide dismutase (SOD) and catalase (CAT), in the supernatant from different brain regions were assayed.

SOD activity was assayed using the nitroblue tetrazolium (NBT) method proposed by Flohe et al. ${ }^{37}$ NBT was reduced to blue formazen by superoxide, which has a strong absorbance at $560 \mathrm{~nm}$. One unit (U) of SOD is defined as the amount of protein that inhibits the rate of NBT reduction by $50 \%$ in $1 \mathrm{~min}$ under the assay conditions. SOD activity was also expressed as units per milligram of protein $(\mathrm{U} / \mathrm{mg}$ protein).

CAT activity was assayed using the method proposed by Pippenger et al. ${ }^{38}$ The method consists in following the change in absorbance of a solution of $\mathrm{H}_{2} \mathrm{O}_{2} 10 \mathrm{mM}$ in potassium phosphate buffer $0.05 \mathrm{M}, \mathrm{pH}=$ 7.4 to $240 \mathrm{~nm}$. One unit of CAT is defined as the amount of enzyme which induces reduction in absorbance of 0.43 at $25^{\circ} \mathrm{C}$ for 3 minutes. CAT activity was also expressed as units per milligram of protein $(\mathrm{U} / \mathrm{mg}$ protein).

The nitrosative stress markers in supernatant from different brain regions were determined by measuring the nitric oxide (NO) level.

The NO production was indirectly detected by measuring the degradation products of NO, the total nitrite level, after a prior conversion of nitrates into nitrites under the action of nitrate reductase. The nitrite plus nitrate (NOx) production was determined by measuring the nitrite, a stable end-product of NO metabolism using the Griess reaction. ${ }^{39}$ The supernatant was mixed with an equal volume of Griess reagent followed by spectrophotometric measurement at $543 \mathrm{~nm}$. Nitrite concentrations in the brain tissue homogenate were determined by comparison with a sodium nitrite standard curve. The NOx levels are presented as nanomole per milligram of protein $(\mathrm{nmol} / \mathrm{mg}$ protein).

\subsection{Statistical analysis}

The statistical analysis was performed using the SPSS software package (version 17.0). The data analyses were performed using one-way analysis of variance (ANOVA) followed by Tukey's multiple comparisons posttest. All of the results were expressed as the means \pm standard deviation (S.D.) from the results of ten rats in each group. P-values less than 0.05 were considered statistically significant. In the graphs we only marked the values that were significantly modified compared to the control groups.

\section{Results}

Brain weight changes of rats under shortterm versus long-term intermittent hypobaric hypoxia

The total brain weigh of rats did not increase significantly following 2 days of exposure to $\mathrm{IHH}$ (STIHH+CMC group) $(1.74 \pm 0.14 \mathrm{~g})$ compared to control group $(1.72 \pm 0.06 \mathrm{~g})$. After 4 weeks of exposure to $\mathrm{IHH}$ (LTIHH+CMC group), the total brain weight increased significantly $(2.04 \pm 0.11 \mathrm{~g}$; $\mathrm{P}<0.05)$ compared to control group $(1.71 \pm 0.05 \mathrm{~g})$. The rats treated with Que and exposed to $\mathrm{IHH}$ for 4 weeks $(1.85 \pm 0.08 \mathrm{~g}$; LTIHH+Que group) showed a significantly decrease in the total brain weight $(P<0.05)$ of compared with animals exposed 4 weeks to $\mathrm{IHH}$ and treated only with vehicle (LTIHH+CMC group).

Effects of Quercetin on lipid peroxidation and proteins carbonylation in different brain 
regions of rats exposed to short-term or long-term intermittent hypobaric hypoxia

Lipid peroxidation. Lipid peroxidation in different brain regions (e.g. striatum, hippocampus and cortex) of experimental rats was determined by measuring the products derived from lipid peroxidation, such as MDA, which represent the most interesting method of indirect determining of free radicals. Lipid peroxidation is a major marker for stress-induced membrane damage. The MDA level in striatum, hippocampus and cortex increased after 2 days $(\mathrm{P}<0.05)$ of exposure to $\mathrm{IHH}$ as compared to control groups, and it was very significantly higher $(P<0.005)$ when the exposure to $\mathrm{IHH}$ was extended to 4 weeks (Figure 1a). After 4 weeks of exposure to $\mathrm{IHH}$, the MDA production was higher in all three brain regions, especially in the hippocampal region of rats, the difference was statistically significant $\quad(P<0.0001)$ (Figure 1a). Treatment of rats with Quercetin, 30 minutes prior to exposure to $\mathrm{IHH}$ resulted in a notable protection against MDA production in all brain regions (e.g. striatum, hippocampus and cortex) of rats both the 2 days after exposure to $\mathrm{IHH}$ $(P<0.05)$ and especially after 4 weeks $(P<0.0005)$ of exposure to $\mathrm{IHH}$ in all rats as compared with animals exposed 2 days or 4 weeks of $\mathrm{IHH}$, respectively and treated only with vehicle (CMC) (Figire 1a).

Protein oxidation. Reactive protein carbonyl derivates have of been measured as an index of brain tissue damage by oxidative stress. The effect of hypoxia on protein oxidation was measured by determining protein carbonyl (PC) content in supernatant of brain tissue homogenate after derivatization with DNPH. A significant marked increase $(P<0.001)$ was observed in protein oxidation in striatum, hippocampus and cortex of rats after 2 days of $\mathrm{IHH}$ exposure compared with their controls (Figure 1b). After 4 weeks of exposure to IHH the PC production was marked increase $(P<0.0001)$ in all brain regions, especially in the hippocampal region of rats, the difference was statistically significant $(P<0.0001)$ (Figure 1b). Quercetin treatment reduced $(P<0.001)$ the carbonyl groups in all three brain regions, especially in the hippocampal region $(P<0.0001)$, of rats exposed 2 days or 4 weeks to $\mathrm{IHH}$ of compared with animals exposed 2 days or 4 weeks of $\mathrm{IHH}$ and treated only with vehicle (CMC) (Figure 1b).

Quercetin protected all if the three brain parts from the lipid peroxidation and protein oxidation induced by $\mathrm{IHH}$ exposure, protection was statistically most significant $(\mathrm{P}<0.0001)$ in hippocampal region in rats exposed to LTIHH (Figure 1). 


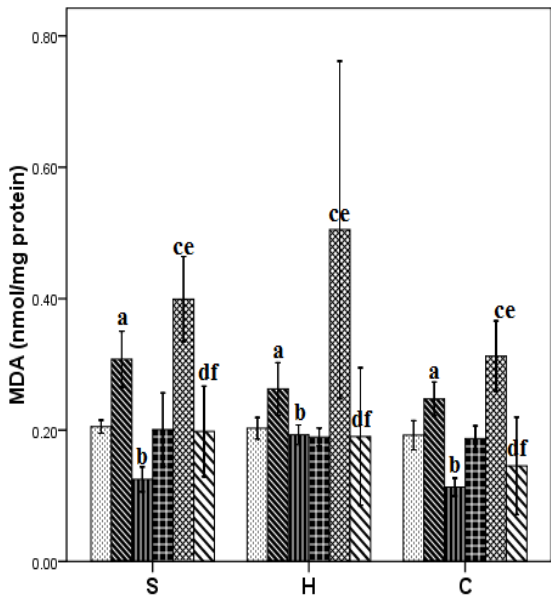

Error bars: +1- 1 SD

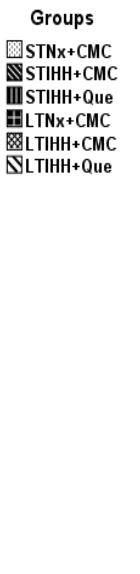

(a)

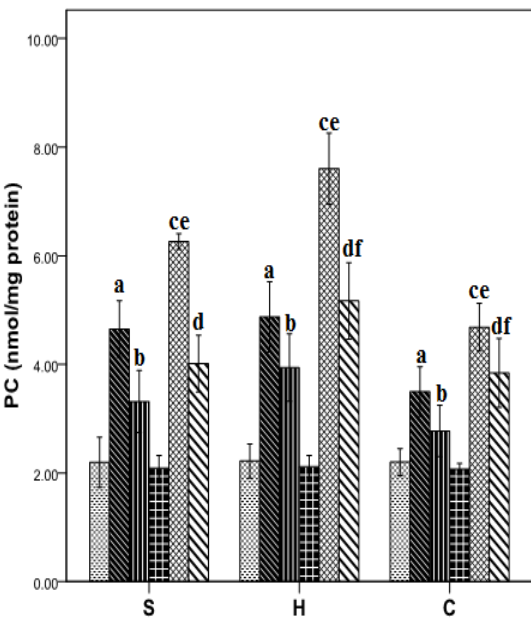

Error bars $+1-1$ SD
Groups

圈STNx+CMC

$\mathbb{N T I H H + C M C}$

IIISTIHH+Que

HLTNx+CMC

圈LTIHH+CMC

DLTIHH+Que

(b)

Figure 1. The modification of oxidative stress markers like free radicals in striatum (S), hippocampus $(\mathrm{H})$ and cortex $(\mathrm{C})$ of rat brain exposed to intermittent hypobaric hypoxia for 2 days or 4 weeks, with carboxymethylcellulose $(C M C)$ or Quercetin (Que) treatment shown by measurement of: (a) malondialdehyde (MDA) (nmol/mg protein) and (b) protein carbonyl groups (PC) (nmol/mg protein). Rats were submitted to 2 days (short-term) or 4 consecutive weeks (long-term) intermittent hypobaric hypoxia (STIHH or LTIHH) or normobaric normoxia $(\mathrm{Nx})$ conditions, with treatment of CMC or Que. Results are the means $\pm S D$ for ten animals in each group. "a" indicates $\mathrm{P}<0.05$ when STIHH+CMC group vs. STNx+CMC group; "b" indicates $\mathrm{P}<0.05$ when $\mathrm{STIHH}+\mathrm{Q}$ ue group vs. STIHH+CMC group; "c" indicates $\mathrm{P}<0.0001$ when $\mathrm{LTIHH}+\mathrm{CMC}$ group vs. $L T N x+C M C$ group; "d"indicates $P<0.005$ when $L T I H H+Q$ ue group vs. $L T I H H+C M C$ group; "e" indicates $\mathrm{P}<0.05$ when $\mathrm{LTIHH}+\mathrm{CMC}$ group vs. STIHH+CMC group; "f"indicates $\mathrm{P}<0.05$ when $\mathrm{LTIHH}+$ Que group vs. STIHH+Que group

Effects of Quercetin on enzymatic antioxidants activity in different brain regions of rats exposed to short-term or long-term intermittent hypobaric hypoxia

As the biomarkers of the antioxidant defenses, the activities of SOD and CAT in different brain regions (e.g. striatum, hippocampus and cortex) of rats were measured (Figure 2). The result indicated that SOD activity lowered significantly $(P<0.05)$ in all three brain regions of the 2 days (STIHH group) or 4 weeks (LTIHH group) exposure groups as compared to the control groups (Figure 2a). The Que treatment significantly augmented $(P<0.05)$ SOD activity in all three brain regions of rats exposed 2 days (Que+STIHH group) or 4 weeks (Que+LTIHH) to $\mathrm{IHH}$ of compared with animals exposed to IHH for 2 days or 4 weeks and treated only with vehicle $(C M C)$, the growth being very statistically significant $(P<0.0001)$ in the striatum and cortex regions in both types of exposure to $\mathrm{IHH}$ (Figure 2a). The activity of CAT decreased significant $(P<0.05)$ in all of the three brain regions of the 2 days (STIHH group) or 4 weeks (LTIHH group) exposure groups in comparison to the control groups (Figure 2b). The Que supplementation very significantly increased $(P<0.0001)$ CAT activity in all three brain regions, similarly in those which were exposed for 2 days to IHH to those exposed for 4 weeks, without a significant difference between the two types of exposure, compared to animals exposed to 
$\mathrm{IHH}$ for 2 days or 4 weeks and treated only with vehicle (CMC) (Figure $2 \mathrm{~b}$ ).

Quercetin protected all the brain parts, especially the hippocampal region, from oxidative stress induced by $\mathrm{IHH}$ exposure, protection evidenced by the increased activity of antioxidant enzymes (SOD and CAT) (Figure 3).

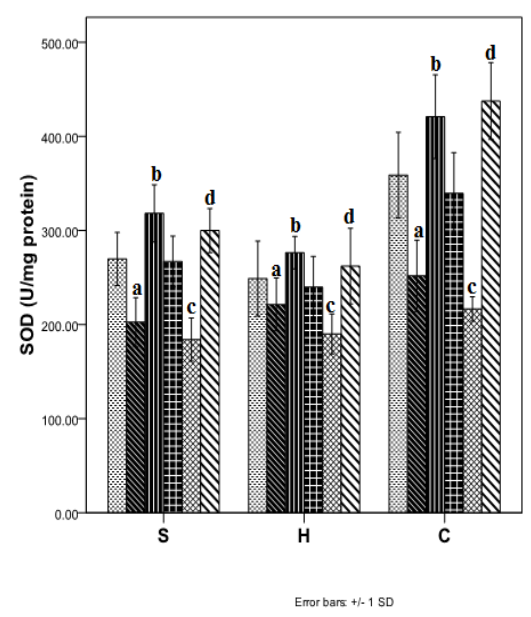

(a)

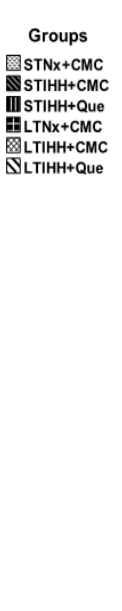

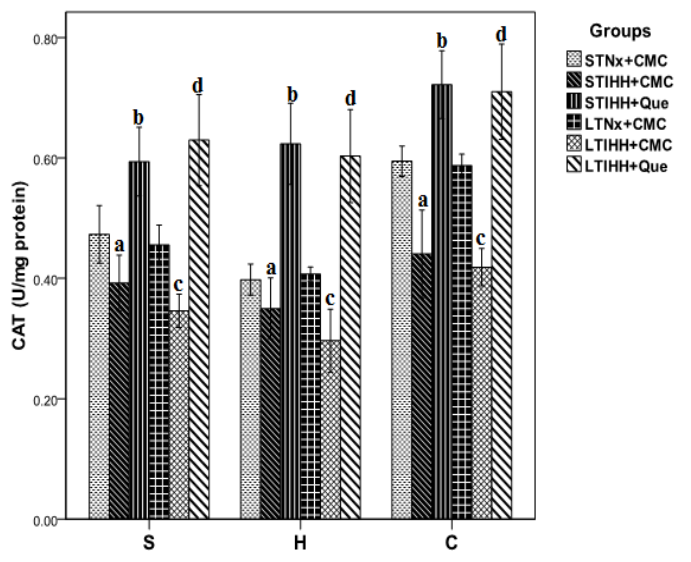

(b)

Figure 2. The brain enzymatic antioxidant activity in striatum (S), hippocampus (H) and cortex (C) of rat brain exposed to intermittent hypobaric hypoxia for 2 days or 4 weeks, with carboxymethylcellulose (CMC) or Quercetin (Que) treatment shown by measurement of: (a) superoxide dismutase (SOD) activity (U/mg protein) and (b) catalase (CAT) activity (U/mg protein). Rats were submitted to short-term (2 days) or long-term (4 consecutive weeks) intermittent hypobaric hypoxia (STIHH or LTIHH) or normobaric normoxia (Nx) conditions, with treatment of $C M C$ or Que. Results are the means \pm SD for ten animals in each group. Results are the means \pm SD for ten animals in each group. "a" indicates $P<0.05$, when 2 days IHH group vs. control group; "b" indicates $\mathrm{P}<0.05$, when Que treatment and 2 days $\mathrm{IHH}$ group vs. control group; "c" indicates $\mathrm{P}<0.05$, when 4 weeks $\mathrm{IHH}$ group vs. control group; "d" indicates $\mathrm{P}<0.05$, when Que treatment and 4 weeks IHH group vs. control group; "e" indicates $P<0.05$, when 2 days IHH group vs. 4 weeks IHH group; "f" indicates $P<0.05$, when Que treatment and 2 days IHH group vs. Que treatment and 4 weeks IHH group

Effects of Quercetin on decreased nitrosative stress in the brain tissue of rats exposed to short-term or long-term intermittent hypobaric hypoxia

Nitrite production. Nitrite as an indicator of NO production was measured. After 2 days of $\mathrm{IHH}$ exposure, the NO production was significantly increased $(P<0.005)$ in all three regions of the rat brain relative to control groups. The nitrite level increased more significantly after 4 weeks $(P<0.0001)$ of $\mathrm{IHH}$ exposure in all three brain regions, especially in the hippocampal region $(P<0.0001)$, compared to animals exposed to $\mathrm{IHH}$ for 4 weeks and treated only with vehicle (CMC) (Figure 3). The Que administration decreased the NO production in all three regions of the brain of the rats exposed 2 days to $\mathrm{IHH}$ compared with the control groups $(P<0.05)$, the decrease being more significant in the rats exposed to $\mathrm{IHH}$ for 4 weeks $(\mathrm{P}<0.0001)$ compared to animals exposed 4 weeks of $\mathrm{IHH}$ and treated only with vehicle (CMC) (Figure $3)$. 


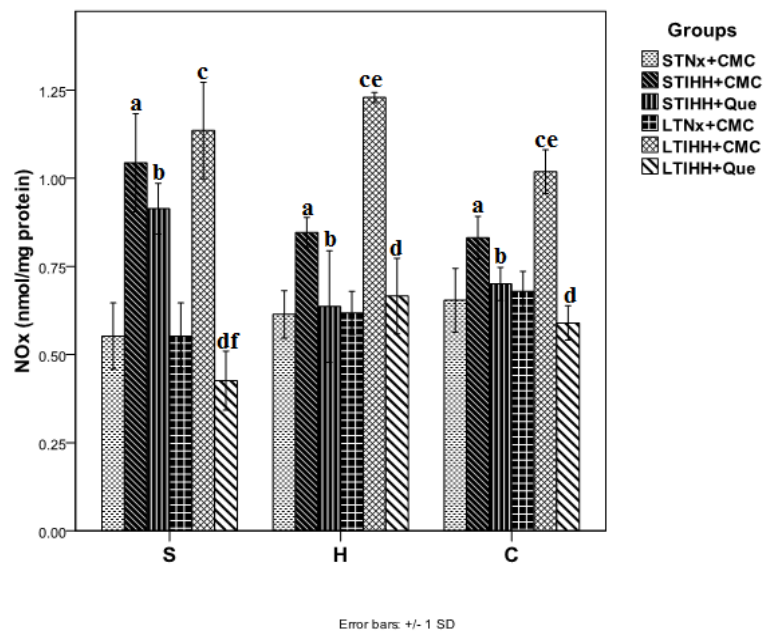

Figure 3. The nitric oxide (NO) production in striatum (S), hippocampus $(\mathrm{H})$ and cortex (C) of rat brain exposed to intermittent hypobaric hypoxia for 2 days or 4 weeks, with carboxymethylcellulose (CMC) or Quercetin (Que) treatment shown by measurement of nitrite plus nitrate (NOx) level ( $\mathrm{nmol} / \mathrm{mg}$ protein). Rats were submitted to short-term (2 days) or longterm (4 consecutive weeks) intermittent hypobaric hypoxia (STIHH or LTIHH) or normobaric normoxia $(\mathrm{Nx})$ conditions, with treatment of carboxymethylcellulose (CMC) or Quercetin (Que). Results are the means \pm SD for ten animals in each group. "a" indicates $P<0.005$, when 2 days IHH group vs. control group; "b" indicates $\mathrm{P}<0.05$, when Que treatment and 2 days $\mathrm{IHH}$ group vs. control group; "c" indicates $\mathrm{P}<0.0001$, when 4 weeks IHH group vs. control group; "d" indicates $\mathrm{P}<0.0001$, when Que treatment and 4 weeks IHH group vs. control group; "e" indicates $\mathrm{P}<0.05$, when 2 days $\mathrm{IHH}$ group vs. 4 weeks IHH group; "f" indicates $\mathrm{P}<0.05$, when Que treatment and 2 days IHH group vs. Que treatment and 4 weeks IHH group

\section{Discussion}

In the present study aimed to investigate the involvement of the oxidative stress and NO system in brain exposure to $\mathrm{IHH}$. We studied the time-dependent and regiondependent changes of same markers of oxidative/nitrosative stress in striatum, hippocampus and cortex after exposure to $\mathrm{IHH}$ for 2 days and 4 weeks and the potential neuroprotective role of natural antioxidants (Quercetin) administration in $\mathrm{IHH}$ neuronal injury using in vivo model. Findings of our study were: (1) the total brain weight was significant increase in rats after 4 weeks of $\mathrm{IHH}$ exposure (LTIHH). However, no significant changes of brain weight has been found in rat after 2 days of IHH exposure; (2) Quercetin administration significantly decreased the brain weight after a long-term
IHH exposure; (3) IHH exposure increased MDA, PC and NO levels in all three regions of the brain (e.g. striatum, hippocampus and cortex) in a time-dependent manner; (4) different regions of the brain were differently affected by $\mathrm{IHH}$ and contained different levels of NO; (5) after the 4 weeks of $\mathrm{IHH}$ exposure, the MDA, PC and NO production more increased and endogen antioxidant enzymes activity (SOD and CAT) was increased in all the three brain regions; (6) the NO system may be involved in increasing oxidative stress and neurodegeneration after $\mathrm{IHH}$; (7) the hippocampus is more vulnerable to $\mathrm{IHH}$ stress than the cortex and striatum; (8) the Quercetin directly scavenges RONS generated during exposure to $\mathrm{IHH}$; (9) in addition to its strong antioxidant properties, Quercetin restores endogenous redox homeostasis by elevating SOD and CAT levels and free radical scavenging enzymes system 
in all the three brain regions; (10) Quercetin acts like a neuroprotectant in IHH. Our major findings imply that changes of brain weight and oxidative/nitrosative stress in the brain under $\mathrm{IHH}$ exposure are tightly time-course dependent and Quercetin administration can provide protection from oxidative/nitrosative stress in hypoxic brain, thus representing a therapeutic strategy in brain protection in ischemia/reperfusion injures.

Exposure to HA is considered to be along with anaerobic physical exercise, pregnancy and ageing an extreme physiological cellular oxidative stress that causes an increased production of RONS which causing damage to lipid, protein and DNA. ${ }^{3,4,40}$ One of the major causes for the neurological disorders is hypoxia and therefore many recent researches have tried to find natural compounds to reduce the effects of hypoxia on the brain. $23,{ }^{28,30,34}$

A significant increased in the total brain weight was observed in our study after 4 weeks of exposure to $\mathrm{IHH}$ as compared to control. After 2 days of $\mathrm{IHH}$ exposure, the rats showed no significant changed of the total brain weight. Our results are in accordance with recent data that have reported increased brain weight; the increase is probably due to dilatation of the blood vessels, which increases permeability of vessels. As a result, an accumulation of tissue fluid in the intracellular spaces that produce increase in brain weight. ${ }^{4}$ The rats treated with Quercetin and exposed 4 weeks to $\mathrm{IHH}$ showed a significant decrease of the total brain weight. Quercetin is one of the most important flavonoid known for its antiinflammatory and neuroprotective properties, which can be used as a potent drug against high altitude cerebral edema, because it efficiently attenuates inflammation and cerebral edema formation. ${ }^{41}$ Decrease in total brain weight after Quercetin administration and 4 weeks of exposure to $\mathrm{IHH}$ we interpreted in this way due to anti-inflammatory and antiedematous effects ${ }^{24,41}$ of this flavonoid, but also because of its ability to pass blood brain barrier (BBB) and inhibitory effect of metalloproteinases (MMPs) enzyme activities. ${ }^{42}$ The pathological effects of MMPs include hemorrhage, edema, inflammation, BBB breakdown and neurovascular matrix degradation. ${ }^{42,43}$

We are investigated the oxidative/nitrosative stress induced in different regions of the rat brain (e.g. striatum, hippocampus and cortex) by $\mathrm{IHH}$ exposure and the possible neuroprotective effects of Quercetin treatment. Our data clearly suggest that $\mathrm{IHH}$ exposure determines a significant generation of free radicals in all three brain regions, the production being more significantly increased after 4 weeks to $\mathrm{IHH}$ exposure. Lipid peroxidation during exposure to $\mathrm{IHH}$, in the present study, was significantly increased especially in the hippocampus region of the brain after 4 weeks exposure to $\mathrm{IHH}$. Supplementation of Quercetin during exposure to $\mathrm{IHH}$ significantly decreased lipid peroxidation and protein oxidation in all three regions of the brain, after two days but especially after 4 weeks of exposure to $\mathrm{IHH}$. At the same time, Quercetin administration further reversed hypoxia-induced decreased antioxidant activity of SOD and CAT in all three regions of the brain, determining a decrease in oxidative stress in the brain. There were similar results of Quercetin effects on the decrease of oxidative stress at the level of the hippocampus that was exposed to hypobaric hypoxia obtained by Prasad et al. ${ }^{23}$ The lowering of lipid peroxidation and protein oxidation and the growth of antioxidant activity of SOD and CAT after Quercetin supplementation could be due to its antioxidant properties. ${ }^{24,26,29}$ Quercetin has potent action against oxidative stress by direct scavenging of free radicals (hydroxyl radicals and superoxide anions), increases endogenous antioxidant enzymes, chelation of iron and calcium, inhibition of lipid peroxidation and some enzymes including xanthine oxidase and NOS. ${ }^{23-44}$ Many recent researches show that NO system plays a role in brain responses to $\mathrm{HH}$ in hippocampus, cerebral cortex and cerebellum. ${ }^{5,16,45}$ The source of increased NO production in the brain after exposure to $\mathrm{HH}$ may be both 
nNOS, determining the growth of nitrosative stress responsible for brain damage. Only nNOS is responsible for production of NO in the brain, because the other isoforms of NOS, iNOS and eNOS, are mainly involved in inflammation, angiogenesis, etc. and predominant in other tissues. ${ }^{16}$ nNOS is synthesized in neurons and generates NO which acts as neurotransmitter and neuromodulator in the non-adrenergic and non-cholinergic nerve endings necessary for communication between nervous cells. ${ }^{19}$ Under the action of nNOS, an excess of NO is produced which is responsible for the brain injury in hypoxia/reoxygenation. ${ }^{14}$ After exposure to $\mathrm{HH}$, the free radicals produced in excess reacted with excess $\mathrm{NO}$ to form peroxynitrite, neurotoxic species, responsible for proteins denaturation, lipid peroxidantion, apoptosis and DNA damage causing destruction determined in the neurons. $^{15,16}$

The present results are shown that after 2 days of $\mathrm{IHH}$ exposure, there was an increased NO production in all three regions of the brain. We have interpreted this higher as being the result of activating NF-KB in the brain tissue after exposure to $\mathrm{IHH}$, which increases the expression of HIF-1 $\alpha$. The HIF$1 \alpha$ in turn expands the generation of NO.,12 $\mathrm{NO}$ produced in excess in the hypoxic brain is responsible for: increasing erythropoiesis, vascularisation and vasodilatation in the brain, and therefore neuroprotection. After exposure to long-term $\mathrm{IHH}$, the NO production in all three regions of the brain increased more significantly, especially in the hippocampal region. Increased production of $\mathrm{NO}$ in all three regions of the brain, especially the hippocampal region, we interpreted as being due to the glutaminergic neurons at this level. Hypoxia stimulates glutaminergic neurons causing increasing intracellular calcium levels by opening calcium channels through NMDA receptors. Increased calcium levels cause nNOS activation and increased synthesis of NO. ${ }^{19,20}$ In this present study, the supplementation with Quercetin in rats exposed to short-term or long-term $\mathrm{IHH}$ showed a significant decrease in the NO produced in all three regions of the brain. We have interpreted these results as due to the natural antioxidant capacity to inhibit NOS. $^{23,24,44}$

Recent researches reported involvement of RONS in mediating oxidative insults during cerebral ischemia and reperfusion result in damage to vulnerable regions of the brain: the hippocampus, hypothalamus, cerebrum and cerebellum. ${ }^{5,16}$ Our results are in accordance with these findings and show a growth in oxidative/nitrosative stress at the level of striatum, hippocampos and cortex after exposure to $\mathrm{IHH}$ : these growths being time-dependent and region-dependent. Results from the present study suggest that Quercetin has neuroprotective effects after exposure to $\mathrm{IHH}$ and modulates its neuroprotective effects by the enhancement of NO bioavailability through the metabolism of superoxide anions and/or its reactive metabolites and by directly scavenging ROS and free radicals and activating antioxidant enzymes, data which were in agreement with other findings recently repored by other authors. $^{31,46,47}$

\section{Conclusion}

In conclusion, our data demonstrate that hippocampus is more vulnerable to oxidative/nitrosative stress induced by exposure to $\mathrm{IHH}$ than the cortex and striatum and Quercetin acts like a neuroprotectant. These beneficial actions of Quercetin were mediated by its antioxidant protection accomplished through directly scavenging RONS generated during exposure to $\mathrm{IHH}$ and through restored endogenous redox homeostasis (by elevating SOD and CAT levels). These findings suggest that Quercetin can be used as a potential therapeutic agent to ameliorate hypobaric hypoxia-induced memory dysfunction and other neurodegenerative disorders, the result of the process of ischemia and reperfusion. 


\section{Acknowledgements}

The authors gratefully acknowledge Remus Moldovan for animal handling. They also thank Nicoleta Decea for her help regarding oxidative/nitrosative stress parameters' assessment.

\section{References}

${ }^{1}$ Bharke, M.; Hale, S. B. Effect of altitude on mood, behavior and cognitive functioning. Sports Medicine 1993, 16, 97. [CrossRef] [PubMed]

${ }^{2}$ Chandel, N. S.; Maltepe, E.; Goldwasser, E.; Mathieu, C. E.; Simon, M. C.; Schumacker, P. T. Mitchondrial reactive species trigger hypoxia induced transcription. Proceedings of the National Academy of Sciences USA 1998, 95, 11715. [CrossRef] [PubMed]

${ }^{3}$ Dosek, A.; Ohmo, H.; Acs, Z.; Taylor, A. W.; Radak, Z. High altitude and oxidative stress. Respiratory Physiology \& Neurobiology 2007, 158, 128. [CrossRef] [PubMed]

${ }^{4}$ Maiti, P.; Singh, S. B.; Sharma, A. K.; Muthuraju, S.; Ilavazhagan, G.; Banerjee, P. K. Hypobaric hypoxia induces oxidative stress in rat brain. Neurochemistry International 2006, 49, 709. [CrossRef] [PubMed]

${ }^{5}$ Romero, R. M.; Canuelo, A.; Siles, E.; Oliver, F. J.; Lara, M. E. Nitric oxide modulates hypoxia-inducible factor-1 and poly (ADPribose) polymerase-1 cross talk in response to hypobaric hypoxia. Journal of Applied Physiology 2012, 112, 816. [CrossRef] [PubMed]

${ }^{6}$ Dringen, R.; Gutterer, J. M. Glutathione metabolism in brain metabolic interaction between astrocytes and neurons in the defense against reactive oxygen species. European Journal of Biochemistry 2000, 267, 4912. [CrossRef] [PubMed]

${ }^{7}$ Maiti, P.; Singh, S. B.; Muthuraju, S.; Veleri, S.; Ilavazhagan, G. Hypobaric hypoxia damages the hippocampal pyramidal neurons in the rat brain. Brain Research 2007, 1175, 1. [CrossRef] [PubMed]
${ }^{8}$ Maiti, P.; Muthuraju, S.; Ilavazhagan, G.; Singh, S. B. Hypobaric hypoxia induces dendritic plasticity in cortical and hippocampal pyramidal neurons in the rat brain. Behavioural Brain Research 2008, 189, 233. [CrossRef] [PubMed]

${ }^{9}$ Maiti, P.; Singh, S. B.; Mallick, B. N.; Muthuraju, S.; llavazhagan, G. High altitude memory impairment is due to neuronal apoptosis in hippocampus, cortex and striatum. Journal of Chemical Neuroanatomy 2008, 36, 227. [CrossRef] [PubMed]

${ }^{10}$ Baitharu, I; Deep, S. N.; Jain, V.; Barhwal, K.; Malhotra, A. S.; Hota, S. K.; Prasada, D.; llavazhagan, G. Corticosterone synthesis inhibitor metyrapone ameliorates chronic hypobaric hypoxia induced memory impairment in rat. Behavioural Brain Research 2012, 228, 53. [CrossRef] [PubMed] ${ }^{11}$ Hota, S. K.; Kalpana, B.; Shashi, B. S.; llavazhagan, G. Chronic hypobaric hypoxia induced apoptosis in CA1 region of hippocampus: a possible role of NMDAR mediated p75NTR upregulation. Experimental Neurology 2008, 212, 5. [CrossRef] [PubMed] ${ }^{12}$ Xie, Q. W.; Kashiwabara, Y.; Nathan, C. Role of transcription factor NF-KB/Rel in induction of nitric oxide synthase. The Journal of Biological Chemistry 1994, 269, 4705. [PubMed]

${ }^{13}$ Kaluz, S.; Kaluzova, M.; Stanbridge, E. J. Regulation of gene expression by hypoxia: integration of the HIF-transduced hypoxic signal at the hypoxia-responsive element. Clinica Chimica Acta 2008, 395, 6. [CrossRef] [PubMed]

${ }^{14}$ Matsui, T.; Nagafuji, T.; Kumanishi, T.; Asano, T. Role of nitric oxide pathogenesis underlying ischemic cerebral damage. Cellular and Molecular Neurobiology 1999, 19, 177. [CrossRef] [PubMed]

${ }^{15} \mathrm{McC}$ ord, J. M. The evolution of free radicals and oxidative stress. The American Journal of Medicine 2000, 198, 652. [CrossRef] [PubMed]

${ }^{16}$ Maiti, P.; Singh, S. B.; Ilavazhagan, G. Nitric oxide system is involved in hypobaric hypoxia-induced oxidative stress in rat brain. Acta Histochemica 2010, 112, 222. [CrossRef] [PubMed] 
${ }^{17}$ Baitharu, I.; Deep, S. N.; Jain, V.; Barhwal, K.; Malhotra, A. S.; Hotab, S. K.; Prasad, D.; Ilavazhagan, G. Corticosterone synthesis inhibitor metyrapone ameliorates chronic hypobaric hypoxia induced memory impairment in rat. Behavioural Brain Research 2012, 228, 53. [CrossRef] [PubMed]

18 Beckman, J. S.; Beckman, T. W.; Chen, J.; Marshall, P. A.; Freeman, B. A. Apparent hydroxyl radical production by peroxynitrite: implication for endothelial injury from nitric oxide and superoxide. Proceedings of the National Academy of Sciences USA 1990, 87, 1620. [CrossRef] [PubMed]

19 Daff, S. NO synthase: structure and mechanisms. Nitric Oxide 2010, 23, 1. [CrossRef]

${ }^{20}$ Nicoll, R.; Malenka, R. C. Contrasting properties of two forms of long-term potentiation in the hippocampus. Nature 1995, 377, 115. [CrossRef] [PubMed]

${ }^{21}$ Hanasaki, Y.; Ogawa, S.; Fukui, S. The correlation between active oxygens scavenging and antioxidative effects of flavonoids. Free Radical Biology and Medicine 1994, 16, 845. [CrossRef] [PubMed]

${ }^{22}$ Tang, D.; Dong, Y.; Ren, H.; Li, L.; He, C. A review of phytochemistry, metabolite changes, and medicinal uses of the common food mung bean and its sprouts (Vigna radiata). Chemistry Central Journal 2014, 8, 4. [CrossRef] [PubMed]

${ }^{23}$ Prasad, J.; Baitharu, I.; Sharma, A. K.; Dutta, R.; Prasad, D.; Singh, S. B. Quercetin reverses hypobaric hypoxia-induced hippocampal neurodegeneration and improves memory function in the rat. High Altitude Medicine \& Biology 2013, 14, 383. [CrossRef] [PubMed]

${ }^{24}$ Boots, A. W.; Haenen, G. R.; Bast, A. Health effects of quercetin: from antioxidant to nutraceutical. European Journal of Pharmacology 2008, 585, 325. [CrossRef] [PubMed]

${ }^{25}$ Chis, I. C.; Baltaru, D.; Marton, A.; Maier M.; Muresan, A.; Clichici, S. Effects of quercetin and chronic (training) exercise on oxidative stress status in animals with streptozotocin-induced diabetes. Bulletin UASVM, Veterinary Medicine 2013, 70, 31. [Link]
${ }^{26}$ Dias, A. S.; Porawski, M.; Alonso, M.; Marroni, N.; Collado, P. S.; González-Gallego, J. Quercetin decreases oxidative stress, NFkappaB activation, and iNOS over expression in liver of streptozotocin-induced diabetic rats. The Journal of Nutrition 2005, 135, 2299. [PubMed]

${ }^{27}$ Bhutada, P.; Mundhada, Y.; Bansod, K.; Bhutada, C.; Tawari S.; Dixit, P.; Mundhada, D. Ameliorative effect of Quercetin on memory dysfunction in streptozotocininduced diabetic rats. Neurobiology of Learning and Memory 2010, 94, 293. [CrossRef] [PubMed]

${ }^{28}$ Dumitrovici, A.; Bolfa, P. F.; Borza, G.; Mureşan, A.; Maier, M.; Vlad, D.; Chiş, I. C. Neuroprotective effects of quercetin, Iycium barbarum and chitosan against of the oxidative stress induced by exposure to hypobaric hypoxia. Bulletin UASVM, Veterinary Medicine 2013, 70, 47. [Link]

${ }^{29}$ Dumitrovici, A.; Mureşan, A.; Simidrea, R.; Chiş, I. C. The effects of the administration of quercetin, lycium barbarum extract and chitosan on oxidative stress induced by exposing rats to hypobaric hypoxia. Indian Journal of Applied Research 2014, 4, 44. [CrossRef]

${ }^{30}$ Sarkar, A.; Angeline, M. S.; Anand, K.; Ambasta, R. K.; Kumar, P. Naringenin and quercetin reverse the effect of hypobaric hypoxia and elicit neuroprotective response in the murine model. Brain Research 2012, 24, 59. [CrossRef] [PubMed]

${ }^{31}$ Richetti, S. K.; Blank, M.; Capiotti, K. M.; Piato, A. L.; Bogo, M. R.; Vianna, M. R. ; Bonana, C. D. Quercetin and rutin prevent scopolamine-induced memory impairment in zebrafish. Behavioural Brain Research 2011, 217, 10. [CrossRef] [PubMed]

${ }^{32}$ Sriraksa, N.; Wattanathorn, J.; Muchimapura, S.; Tiamkao, S.; Brown, K.; Chaisiwamongkol, K. Cognitive-enhancing efect of quercetin in a rat model of Parkinson's disease induced by 6hydroxydopamine. Evidence-Based Complementary and Alternative Medicine 2012, 823206. [CrossRef] [PubMed]

${ }^{33}$ Tchantchou, F.; Lacor, P. N.; Cao, Z.; Lao, L.; Hou, Y.; Cui, C.; Klein, W. L.; Luo, Y. 
Stimulation of neurogenesis and synaptogenesis by bilobalide and quercetin via common final pathway in hippocampal neurons. Journal of Alzheimer's Disease 2009, 18, 787. [CrossRef] [PubMed]

${ }^{34}$ Jung, W. Y.; Park, S. J.; Park, D. H.; Kim, J. M.; Kim, D. M.; Ryu, J. H. Quercetin impairs learning and memory in normal mice via suppresionof hippocampal phosphorylated cyclic AMP response element-binding protein expression. Toxicology Letters 2010, 197, 97. [CrossRef] [PubMed]

${ }^{35}$ Conti, M.; Morand, P. C.; Levillain, P. Improved fluorimetric determination of malonaldehyde. Clinical Chemistry 1991, 37, 1273. [PubMed]

${ }^{36}$ Reznick, A. Z.; Packer, L. Oxidative damage to proteins: spectrophotometric method for carbonyl assay. Methods in Enzymology 1994, 233, 347. [CrossRef] [PubMed]

${ }^{37}$ Flohe, L.; Becker, R.; Brigelius, R.; Lengfelder, E; Otting, F.; Convenient assays for superoxide dismutase. In: CRC Handbook of Free Radicals and Antioxidants in Biomedicine; Miguel, J.; Quintanilha, A. T.; Weber, H., eds.; CRC Press: Boca Raton, 1990, 287.

${ }^{38}$ Pippenger, C. E.; Browne, R. W.; Armstrong, D. Regulatory antioxidant enzymes. In: Methods in Molecular Biology, vol. 108: Free Radicals and Antioxidant Protocols D. Armstrong. Humana Press Inc. Totowa NJ. 1998, 299.

${ }^{39}$ Titherage. M. A. The enzymatic measurement of nitrate and nitrite. In: Methods in molecular biology. Nitric oxide protocols. Humana Press, Totowa, NJ. 1998, 100,83

${ }^{40}$ Droge, W. Free radicals in the physiological control and cell function. Physiological Reviews 2002, 82, 47. [CrossRef] [PubMed]
${ }^{41}$ Patir, H.; Sarada, S. K.; Singh, S.; Mathew, T.; Singh, B.; Bansal, A. Quercetin as a prophylactic measure against high altitude cerebral edema. Free Radical Biology and Medicine 2012, 53, 659. [CrossRef] [PubMed]

${ }^{42}$ Cho, J. Y.; Kim I. S.; Jang, Y. H.; Kim, A. R.; Lee, S. R. Protective effect of quercetin, a natural flavonoid against neuronal damage after transient global cerebral ischemia. Neuroscience Letters 2006, 404, 330. [CrossRef] [PubMed]

${ }^{43}$ Rosenberg, G. A. Matrix metalloproteinases in brain injury. Journal of Neurotrauma 1995, 12, 883. [CrossRef] ${ }^{44}$ Zhou, J.; Zhou, S.; Gao, Y.; Zeng, S. Modulatory effects of quercetin on hypobaric hypoxic rats. European Journal of Pharmacology 2012, 674, 450. [CrossRef] [PubMed]

${ }^{45}$ Serrano, J.; Encinas, J. M.; Fernandez, A. P.; Rodrigo, J.; Martinez, A. Effects of acute hypobaric hypoxia on the nitric oxide system of the rat cerebral cortex: protective role of nitric oxide inhibitors. Neuroscience 2006, 142, 799. [CrossRef] [PubMed]

${ }^{46}$ Zhu, X. H.; Yan, H. C.; Zhang, J.; Qu, H. D.; Qiu, X. S.; Chen, L.; Li, S. J.; Cao, X.; Bean, J. C.; Chen, L. H.; Qin, X. H.; Liu, J. H.; Bai, X. C.; Mei, L.; Gao, T. M. Intermittent hypoxia promotes hippocampal neurogenesis and produces antidepressant-like effects in adult rats. The Journal of Neuroscience 2010, 30, 12653. [CrossRef] [PubMed]

${ }^{47}$ Rybnikova, E.; Vorobyev, M.; Pivina, S.; Samoilov, M. Postconditioning by mild hypoxic exposures reduces rat brain injury caused by severe hypoxia. Neuroscience Letters 2012, 513, 100. [CrossRef] [PubMed] 